\title{
PENGARUH PEMBERIAN PROBIOTIK KOMERSIL TERHADAP BOBOT TELUR, PERSENTASE ALBUMIN DAN KUNING TELUR AYAM HASIL PERSILANGAN (GRADING UP)
}

\section{The Effect of Supplementation of Commercial Probiotics on Egg Weight, Percentages of Albumin and Egg Yolk of Crossbreed Chicken (Grading Up)}

\author{
Rudy Sutrisna*, Putri Mayangsari, Riyanti, Khaira Nova \\ Department of Animal Husbandry, Faculty of Agriculture, University of Lampung \\ Soemantri Brojonegoro No.1 Gedong Meneng Bandar Lampung 35145 \\ *E-mail : rudysutrisna65@yahoo.co.id
}

Submitted : December 31, 2019 Accepted : March 27, 2020

\begin{abstract}
ABSTRAK
Tujuan penelitian ini adalah (1) mempelajari pengaruh probiotik komersial yang berbeda terhadap berat telur, persentase albumin dan persentase kuning telur ayam petelur persilangan antara pejantan Lohman dan betina ayam kampung, (2) menentukan probiotik komersial yang dapat memberikan pengaruh terbaik pada berat telur, persentase albumin dan persentase kuning telur ayam petelur persilangan. Penelitian ini dilakukan pada Januari-Februari 2019, pemeliharaan dilakukan di Laboratorium Lapangan Terpadu Fakultas Pertanian Universitas Lampung dan pengumpulan data dilakukan di Laboratorium Produksi dan Reproduksi Ternak Jurusan Peternakan Fakultas Pertanian Universitas Lampung. Penelitian ini menggunakan Rancangan Acak Lengkap (RAL) yang terdiri dari 4 perlakuan dan 7 ulangan berupa suplementasi pada air minum (P0: tanpa probiotik, P1: suplementasi probiotik A, P2: suplementasi probiotik B, P3: suplementasi probiotik C). Penelitian ini menggunakan 28 butir telur dari 28 ekor ayam kampung persilangan umur 64 minggu dan masing-masing unit perlakuan menggunakan satu butir telur. Hasil studi ini menunjukkan bahwa suplementasi probiotik komersial yang berbeda tidak memiliki efek signifikan $(\mathrm{P}>0,05)$ pada berat telur, persentase albumen, dan persentase kuning telur. Simpulan penelitian ini bahwa suplementasi probiotik komersil melalui air minum tidak berpengaruh nyata terhadap bobot telur, persentase albumin dan persentase yolk telur ayam hasil persilangan (grading up) namun pemberian probiotik B menghasilkan bobot telur dan persentase yolk telur ayam hasil persilangan (grading up) lebih besar dibandingkan perlakuan lainnya.
\end{abstract}

Kata kunci: Albumin, Ayam Persilangan, Bobot Telur, Kuning Telur, Probiotik komersial.

\section{ABSTRACT}

The purpose of this research were (1) to study the effect of different commercial probiotics on egg weight, albumin percentage, and yolk percentage of crossbreed chicken (cross between male Lohman and native chicken), (2) to determine the commercials probiotics that can give the best influence on egg weight, albumin percentage, and yolk percentage of layer crossbreed. This research was conducted from January to February 2019 at the Laboratory of Integrated Field, Faculty of Agriculture, University of Lampung. Data collection was carried out in the Laboratory of Animal Production and Reproduction, Faculty of Agriculture, University of Lampung. This research used a completely randomized design (CRD), consisting of four treatments and seven replications, namely drinking water (P0: without probiotic, P1: Probiotic A supplementation, P2: Probiotic B supplementation, and P3: Probiotic C supplementation). This research were used 28 eggs from 28 crossbreed chickens at 64 weeks of age and each treatment unit used one egg. The results of this study showed that different commercial probiotics supplementation had no significant effect $(P>0.05)$ on egg weight, albumen percentage, and yolk percentage. The conclusion of this study was that supplementation of commercial probiotics through drinking water has no significant effect on egg weight, percentage of albumin and percentage of yolk, but administration of probiotic B increased egg weight and percentage of yolk of crossbreed chicken (grading up) greater than other treatments.

Keywords: Albumin, Commercial probiotics, Crossbreed Chicken, Egg weight, Yolk. 


\section{PENDAHULUAN}

Ayam buras atau dikenal di masyarakat sebagai ayam kampung memiliki keunggulan yaitu tidak membutuhkan lahan yang luas untuk proses pemeliharaan, penyediaan pakan mudah dan murah dibandingkan ayam ras namun terdapat beberapa kendala dalam usaha mengembangkannya yaitu sistem pemeliharaan masih tradisional, produksi telur rendah, tingkat kematian tinggi dan pemberian pakan belum sesuai dengan kebutuhan baik kuantitas maupun kualitasnya, maka perlu adanya perbaikan mutu genetik agar dapat meningkatkan kualitas produksi. Salah satu usaha yang dilakukan adalah dengan adanya persilangan ayam kampung dan ayam ras

Ayam Lohmann Brown termasuk salah satu jenis ayam ras penghasil telur yang cukup potensial. Ukuran telur ayam Lohmann Brown lebih kecil dibandingkan dengan telur Isa Brown, jumlah telur yang dihasilkan dalam setahun mencapai 305 butir/ekor dengan bobot telur ratarata mencapai 58--60 g. Persilangan indukan ayam buras dengan pejantan ayam Lohmann Brown diharapkan dapat memperbaiki produktivitas dari ayam buras yang dapat dilihat dari produksi dan kualitas telur yang dihasilkan.

Salah satu faktor yang dapat berpengaruh terhadap produktivitas ayam petelur adalah kualitas pakan yang diberikan. Nutrien dalam ransum yang dapat memengaruhi kualitas telur, antara lain protein, mineral, dan vitamin. Upaya untuk meningkatkan kualitas ransum dilakukan dengan penambahan feed additive.

Antibiotik merupakan salah satu bahan feed additive yang telah lama dipakai di dalam ransum untuk meningkatkan pertumbuhan, efisiensi pakan, dan mengurangi penyakit yang dapat berdampak pada produktivitas ternak tetapi, terdapat dampak negatif penggunaan antibiotik terhadap ternak maupun manusia. Antibiotik yang diberikan pada ternak dapat menyebabkan mikroorganisme yang resisten dalam tubuh ternak terutama bakteri-bakteri patogen seperti Salmonella, Eschericia coli dan Clostridium perfinens (Sarwono et al., 2012). Menurut Bonner (1997) antibiotik mengalami penyerapan dalam saluran pencernaan sehingga meninggalkan residu dalam tubuh ternak. Zat aditif yang diduga dapat menggantikan penggunaan antibiotik adalah probiotik.

Probiotik dikenal sebagai mikroorganisme hidup baik berupa bakteri maupun jamur. Penggunaan probiotik telah banyak dilakukan di kalangan peternak karena mempunyai berbagai fungsi, antara lain mampu meningkatkan pertumbuhan dan efisiensi pakan, mencegah radang usus dan diare, meningkatkan produksi telur dan memperbaiki kualitas telur. Probiotik yang umumnya beredar dipasaran merupakan probiotik komersil berbentuk sediaan cair seperti probiotik A, B, dan C.

Mekanisme kerja probiotik diduga dapat mengoptimalkan penyerapan nutrisi sehingga memberikan sumbangan nutrisi sebagai bahan dalam proses pembentukan telur yang pada akhirnya akan berpengaruh pada kualitas telur. Kualitas telur dinilai dari beberapa indikator diantaranya yaitu bobot telur. Berdasarkan uraian tersebut, maka perlu dilakukan penelitian untuk mempelajari pengaruh pemberian probiotik komersil terhadap bobot telur, persentase albumin dan persentase yolk.

\section{MATERI DAN METODE}

\section{Materi}

Penelitian ini dilaksanakan pada Januari-Februari 2019. Pemeliharaan ayam petelur silangan dilakukan di Laboratorium Lapang Terpadu Fakultas Pertanian Universitas Lampung dan proses pengambilan data dilakukan di Laboratorium Nutrisi dan Makanan Ternak Jurusan Peternakan Universitas Lampung.

Peralatan yang digunakan yaitu kandang sebanyak 28 unit, feeder trough, tempat minum, thermohygometer, gelas ukur plastik, disposable syringe $1 \mathrm{ml}$, timbangan kapasitas $10 \mathrm{~kg}$, timbangan analitik, karung, terpal, alat-alat kebersihan, egg separator, dan gelas piala.

Bahan yang digunakan yaitu ayam induk hasil persilangan (grading up) berjumlah 28 ekor umur 64 minggu, ransum yang digunakan pada penelitian ini adalah ransum racikan berbentuk tepung (mash). Bahan penyusun ransum terdiri atas jagung, dedak padi halus, tepung ikan, mineral feed suplement, lysine, dan methionine, probiotik komersil A, B, dan C, air minum, dan telur ayam persilangan sebanyak 28 butir. Komposisi dan kandungan probiotik komersil dapat dilihat pada Tabel 1 .

\section{Metode}

Penelitian ini dilakukan secara eksperimental menggunakan rancangan acak lengkap (RAL), terdiri atas 4 perlakuan dan 7 ulangan. Masing-masing perlakuan terdiri atas 1 ekor ayam sehingga terdapat 28 petak percobaan. Perlakuan probiotik yang digunakan yaitu:

P0 : air minum tanpa probiotik

P1 : air minum dengan suplementasi probiotik A $0,1 \mathrm{ml} / 100 \mathrm{ml}$ air minum 
P2 : air minum dengan suplementasi probiotik B 0,1 ml/100 $\mathrm{ml}$ air minum

P3 : air minum dengan suplementasi probiotik C 0,1 ml/100 $\mathrm{ml}$ air minum

\section{Analisis Data}

Data yang diperoleh di analisis ragam (Analysis of Variance) pada taraf nyata 5\%., jika diperoleh hasil yang berbeda nyata maka dilakukan Uji Beda Nyata Terkecil (BNT) (Steel dan Torrie, 1993).

\section{Peubah yang Diamati}

Peubah yang diamati pada penelitian ini adalah bobot telur, persentase albumin dan persentase yolk.

\section{HASIL DAN PEMBAHASAN}

Hasil penelitian terhadap bobot telur, persentase albumin dan persentase yolk telur ayam hasil persilangan disajikan pada Tabel 2.

\section{Bobot Telur}

Hasil analisis ragam menunjukkan bahwa pemberian air minum dengan penambahan probiotik tidak berbeda nyata $(\mathrm{P}>0,05)$ terhadap bobot telur ayam persilangan. Rata-rata bobot telur berkisar antara 48,82--50,27 g/butir (Tabel 2). Bobot telur ayam persilangan masih dibawah berat rata-rata telur ayam Lohmann
Brown yaitu sebesar 63,5--65,5 g/butir (Yusri, 2015) namun lebih besar dibandingkan bobot telur ayam buras yaitu sebesar 35 g/butir (Rasyaf, 1998).

Pemberian probiotik pada air minum tidak berpengaruh nyata terhadap bobot telur diduga karena belum optimalnya dosis yang diberikan. Konsentrasi yang dianggap dapat digunakan sebagai probiotik yaitu sebesar $10^{7} \mathrm{sel} / \mathrm{ml}$ pada saat dikonsumsi (Gomes dan Malcata, 1999). Pal et al. (2006) menambahkan bahwa mikroorganisme probiotik tersebut harus bakteri Gram positif, anti Escherichia coli dan minimal mengandung $30 \times 10^{9} \mathrm{CFU} / \mathrm{g}$, konsentrasi yang direkomendasi untuk hampir semua probiotik yaitu $10^{8} \mathrm{CFU} / \mathrm{mg}$ pakan. Jumlah sel bakteri hidup yang harus terdapat dalam produk probiotik dan dapat memberi manfaat kesehatan umumnya berkisar $10^{6}-10^{8} \mathrm{CFU} / \mathrm{g}$ (Tannock, 1999) atau $10^{7}-10^{8} \mathrm{CFU} / \mathrm{g}$ produk (Charterist et al., 1998).

Kandungan bakteri pada masing-masing perlakuan P1, P2, dan P3 ternyata belum mampu memengaruhi komposisi dan ekosistem mikroflora saluran pencernaan ayam persilangan sehingga tidak menunjukkan perbedaan penyerapan nutrisi ransum semua perlakuan. Hasil yang didapat sejalan dengan penelitian Toriq et al. (2017) bahwa pemberian probiotik Lactobacillus fermentum pada air minum tidak berpengaruh nyata terhadap bobot telur ayam petelur menjelang afkir.

Tabel 1. Kandungan probiotik

(The Content of probiotics)

\begin{tabular}{|c|c|c|}
\hline Probiotik & Kandungan mikroba & Jumlah \\
\hline (Probiotics) & (Microbe content) & (Total) \\
\hline \multirow{3}{*}{ A } & Lactobacillus casei & $1,5 \times 10^{5} \mathrm{CFU} / 100 \mathrm{ml}$ \\
\hline & Saccharomyces cereviceae & $1,5 \times 10^{5} \mathrm{CFU} / 100 \mathrm{ml}$ \\
\hline & Rhosopseudomonas palustris & $1,0 \times 10^{5} \mathrm{CFU} / 100 \mathrm{ml}$ \\
\hline B & $\begin{array}{l}\text { Lactobacilus acidophylus, L. plantarum, } \\
\text { L. sulivarius, Bacillus subtilis } \\
\text { Biffidobacterium loguum, B. bifidum, dan Saccharomyces } \\
\text { cereviceae }\end{array}$ & $1,0 \times 10^{7-8} \mathrm{CFU} / 100 \mathrm{ml}$ \\
\hline $\mathrm{C}$ & $\begin{array}{l}\text { Total cell (Lactobacillus acidophylus, L. Plantarum, } L . \\
\text { sulivarius, Biffidobacterium longum, B. bifidium (bakteri } \\
\text { asam laktat), dan S. Cereviceae) }\end{array}$ & $\pm 5,6 \times 10^{6} \mathrm{CFU} / 100 \mathrm{ml}$ \\
\hline
\end{tabular}

Tabel 2. Pengaruh perlakuan terhadap bobot telur, persentase albumen, dan yolk

(Effect of treatment on egg weight, percentages of albumin and yolk)

\begin{tabular}{ccccc}
\hline \multirow{2}{*}{$\begin{array}{c}\text { Peubah } \\
\text { (Variable) }\end{array}$} & P0 & P1 & P2 & P3 \\
\cline { 2 - 5 } & $50,04 \pm 3,57$ & $49,05 \pm 1,47$ & $50,27 \pm 2,54$ & $48,82 \pm 2,68$ \\
Bobot telur (g/butir) & $50,26 \pm 2,54$ & $51,13 \pm 1,44$ & $48,97 \pm 2,07$ & $49,14 \pm 1,27$ \\
Persentase albumen $(\%)$ & $27,60 \pm 1,64$ & $26,67 \pm 1,08$ & $29,01 \pm 1,35$ & $27,61 \pm 0,79$ \\
Persentase yolk (\%) & \multicolumn{4}{c}{} \\
\hline
\end{tabular}




\section{Persentase Albumin}

Hasil analisis ragam menunjukkan bahwa pemberian produk probiotik komersil tidak berbeda nyata $(\mathrm{P}>0,05)$ terhadap persentase albumin. Rata-rata persentase albumin (Tabel 2) berkisar antara 48,97--51,13\%. Persentase albumin masih dibawah standar yang dinyatakan oleh Kurtini et al. (2014) bahwa persentase albumin telur berkisar antara 56--61\%. Sulandari et al. (2007) menambahkan bahwa berat albumin pada telur ayam kampung sebesar 21,67 g dengan persentase sebesar 57,33\%.

Pemberian probiotik komersil (A, B, dan C) tidak memberikan pengaruh yang nyata terhadap persentase albumin diduga disebabkan karena adanya penurunan jumlah bakteri yang langsung diberikan dalam air minum tanpa adanya zat pelindung bakteri. Probiotik sangat sensitif terhadap cekaman lingkungan seperti keasaman, oksigen, dan panas (Soccol et al., 2010).

Berbagai laporan menunjukkan terjadinya penurunan tingkat kelangsungan hidup probiotik dalam produk yang mengandung sel bebas tanpa adanya zat pelindung bakteri. Sultana et al. (2000) melaporkan bahwa viabilitas probiotik tanpa enkapsulasi mengalami penurunan sebesar $1 \mathrm{log}$ $\mathrm{CFU} / \mathrm{ml}$ selama delapan minggu penyimpanan dingin. Jumlah probiotik tanpa enkapsulasi juga menurun sebesar 1-5 log CFU/ml setelah melewati kondisi asam ( $\mathrm{pH}$ 2) dan konsentrasi garam empedu $2 \%$ sebagai simulasi kondisi lambung dan usus halus pada saluran pencernaan, selain itu persentase albumin tidak berbeda nyata dengan perlakuan kontrol (P0) diduga disebabkan oleh kinerja bakteri probiotik yang belum optimal. Menurut Samadi (2004) jenis mikroorganisme seperti Saccharomyces cereviceae dapat meghasilkan enzim protease. Bacillus sp. selain Saccharomyces cereviceae dalam probiotik mampu meningkatkan daya cerna dan juga dapat mengsekresikan enzim protease (Hartono dan Kurtini, 2015). Enzim protease akan membantu dalam proses pencernaan protein menjadi asam amino sebagai bahan untuk proses pembentukan albumin telur.

Albumin telur mengandung sebagian besar protein (10,6--11,3\%) dibandingkan dengan komponen lainnya seperti lemak $(0,03--0,08 \%)$, karbohidrat (0,9--1,3\%), dan mineral (0,6--0,8 \%) (Mushawwir dan Latipudin, 2013). Kinerja Saccharomyces cereviceae dan Bacillus sp yang belum optimal menghasilkan enzim protease menyebabkan tidak adanya perbedaan penyerapan nutrisi terutama protein ransum. Bidura et al. (2008) menyatakan bahwa persentase putih telur dipengaruhi oleh kepadatan albumin, semakin padat albumin maka putih telur yang didapatkan semakin berat, selain itu juga dipengaruhi asupan nutrien yang dibutuhkan untuk pembentukan telur (protein, mineral, vitamin) (Astawa et al., 2018).

\section{Persentase Yolk}

Hasil analisis ragam menunjukkan bahwa pemberian air minum perlakuan dengan penambahan probiotik tidak berbeda nyata ( $>0$ 0,05) terhadap persentase yolk. Rata-rata persentase yolk (Tabel 2) berkisar antara 26,67-$29,01 \%$. Hal ini menunjukkan bahwa pemberian probiotik komersil belum menunjukkan pengaruhnya terhadap persentase yolk. Persentase yolk ayam persilangan sudah memenuhi standar yang disebutkan Kurtini et al., (2014) sebesar 27--32 \%., meskipun secara statistik berpengaruh tidak nyata. Namun, berbeda dengan pendapat Sulandari et al. (2007), yang menyatakan bahwa berat yolk telur ayam kampung sebesar $11,57 \mathrm{~g}$ dengan persentase $30,61 \%$.

Pemberian probiotik komersil tidak memberikan pengaruh yang nyata terhadap persentase yolk diduga karena konsumsi ransum ayam persilangan yang tidak berbeda nyata. Tugiyanti dan Iriyanti (2012) menyatakan salah satu faktor yang memengaruhi berat kuning telur adalah konsumsi ransum. Konsumsi ransum pada masing-masing perlakuan relatif sama sehingga persentase yolk yang dihasilkan tidak berbeda.

Kandungan bakteri proteolitik yaitu Bacillus subtilis dalam probiotik B dapat mensekresikan enzim protease dan lipase yang berperan dalam penguraian protein menjadi asam amino dan penguraian lemak menjadi asam lemak yang menjadi bahan utama pembentukan yolk (Hartono dan Kurtini, 2015). Yolk hanya mengandung kurang lebih $50 \%$ air, selebihnya adalah protein dan lipid dengan perbandingan 1:2 (Mushawwir dan Latipudin, 2013)

Selain itu, persentase yolk yang tidak berbeda nyata diduga disebabkan oleh umur ayam penelitian yang sudah memasuki fase produksi II. Menurut Santoso dan Piliang (2004), umur ayam memengaruhi kandungan trigliserida di dalam serum darah. Semakin tinggi umur maka kandungan trigliseridanya semakin meningkat sehingga kadar trigliserida dalam dalam darah sangat tinggi. Kadar trigliserida yang semakin tinggi memengaruhi volume kuning telur yang dihasilkan. Kuning telur banyak mengandung lemak, lemak kuning telur sebagian besar terdiri atas trigliserida, yaitu sekitar 65,5\%. (Stadelmann dan Cotterill, 1995). 


\section{Simpulan}

\section{SIMPULAN}

Suplementasi probiotik komersil melalui air minum tidak berpengaruh nyata terhadap bobot telur, persentase albumin dan persentase yolk telur ayam hasil persilangan (grading up) namun pemberian probiotik $\mathrm{B}$ menghasilkan bobot telur dan persentase yolk telur ayam hasil persilangan (grading up) lebih besar dibandingkan perlakuan lainnya.

\section{Saran}

Berdasarkan hasil penelitian ini, penulis menyarankan hendaknya dilakukan penelitian lebih lanjut pada ayam petelur silangan atau jenis unggas yang lain dengan umur yang berbeda menggunakan probiotik komersil yang diaplikasikan dalam ransum.

\section{DAFTAR PUSTAKA}

Astawa. I G.G., I G. N. G. Bidura, dan A. A. P. P. Wibawa. 2018. Pengaruh pemberian probiotik Saccharomyces spp. GB-7 dan GB-9 dalam ransum terhadap kualitas fisik telur ayam Lohman Brown umur 40--48 minggu. e-Journal Peternakan. 6(3): 684694.

Bidura, I.G.N.G., L. G. Sumardani, T. I. Putri, dan I. B.G Pertama. 2008. Pengaruh pemberian ransum terfermentasi terhadap pertambahan berat badan, karkas, dan jumlah lemak abdomen pada itik bali. $J$. Pengembangan Peternakan Tropis 33 (4) : 274--281.

Bonner, J. 1997. Hooked on drugs: Farm animal given antibiotics need less food to grow. Is this use of drugs destroying a key weapon against human disease. New Scientist. 153: 24-32.

Charterist, W.P., P.M. Kelly, L. Morelli and J.K. Collins. 1998. Ingredient selection criteria for probiotic microorganism in functional dairy food. Int. J. Dairy Tech. 51: 123135.

Gomes, A.M.P. and F.X. Malcata. 1999. Bifidobacterium spp. and Lactobacillus acidophilus: biological, biochemical, technological and therapeutical properties relevant for use as probiotics. Trends Food. Sci. Technol. 10: 139-157.

Hartono, M., dan T. Kurtini. 2015. Pengaruh pemberian probiotik terhadap performa ayam petelur. J. Penelitian Pertanian Terapan. Vol 15 (3): 214-219.
Kurtini, T., K. Nova., D. Septinova. 2014. Produksi Ternak Unggas. Anugrah Utama Raharja. Bandar Lampung.

Mushawwir, A. dan D. Latipudin. 2013. Biologi Sintesis Telur. Yogyakarta. Graha Ilmu.

Pal, A., L. Ray, P. Chattophadhyay. 2006. Purification and immobilization of an aspergillus terreus xylanase: use of continuous fluidized column reactor. Ind. J. Biotechnol. 5: 163-168.

Rasyaf. 1998. Beternak Ayam Kampung. Penebar Swadaya. Jakarta.

Sarwono, S.R., T. Yudiarti, E. Suprijatna. 2012. Pengaruh pemberian probiotik terhadap trigliserida darah, lemak abdominal, bobot dan panjang saluran pencernaan ayam kampung. Animal Agriculture J. 1(2): 157167.

Samadi. 2004. Feed quality for food safety, kapankah di Indonesia. J. Inovasi 2(16) : 33--35.

Santoso, U. dan W. Piliang. 2004. Penggunaan Ekstrak Daun Katuk Sebagai Feed Additive Untuk Memproduksi Meat Designer. Laporan Penelitian. Universitas Bengkulu. Bengkulu.

Soccol, C.R., L.P. de Souza Vandenberghe, M.R. Spier, A.B.P. Medeiros, C.T. Yamaguishi, J.D.D. Lindner, A. Pandey, V. ThomazSoccol. 2010. The potential of probiotics: a review. Food Technology Biotechnology. 48: 413-434.

Stadelmann, W.J. and O.J. Cotterill. 1995. Egg Science and Technology. 4th ed. Feed Products Press. An Imprint of the Haworth Press, Inc. New York.

Steel, R.G.D dan J.H. Torrie. 1993. Prinsip dan Prosedur Statistika. Terjemahan Bambang Sumantri. Gramedia. Jakarta.

Sulandari, S., M. S. A. Zein, S.T. Paryanti, Sartika, M. Astuti, T. Widjastuti, E. Sudjana, S. Darana, I. Setiawan, D. Garnida. 2007. Sumberdaya Genetik Ayam Lokal Indonesia. Prosiding Seminar Keanekaragaman Sumber Daya Hayati Ayam Lokal Indonesia : Manfaat dan Potensi. Pusat Penelitian Biologi, Lembaga Ilmu Pengetahuan Indonesia. Bandung.

Sultana, K.,G. Godward, N. Reynolds, R. Arumugaswamy, P. Peiris, K. Kailasapathy. 2000. Encapsulation of probiotic bacteria with alginate starch and evaluation of survival in simulated gastrointestinal conditions and in yoghurt. Inter. J. Food Microbiol. 62: 47-55. 
Tannock, G.W. 1999. Probiotic: A Critical Review. Horizon Scientific Press. England. pp. 5-14.

Toriq, J., U. Kalsum, M.F. Wadjdi. 2017. Pengaruh pemberian probiotik lactobacillus fermentum pada air minum terhadap bobot telur dan kualitas eksterior telur ayam petelur menjelang afkir. Dinamika Rekasatwa. 2:1--7.

Tugiyanti, E. dan N. Iriyanti. 2012. Kualitas eksternal telur ayam petelur yang mendapat ransum dengan penambahan tepung ikan terfermentasi menggunakan isolat prosedur anti histamin. J. Aplikasi Teknologi Pangan. 1(2) : 44--47.

Yusri. 2015. Performa Ayam Ras Petelur Pada Periode Awal Bertelur Dengan Kombinasi Berat Badan Pre-Layer dan Pemberian Jumlah Pakan Yang Berbeda. Skripsi. Universitas Hasanudin. Makasar. 